\title{
A new species of Andiceras Krantz (Cephalopoda: Ammonoidea) from the Late Jurassic-Early Cretaceous of the Neuquén Basin, Mendoza, Argentina. Systematics and Biostratigraphy
}

\author{
Verónica V. Vennari' ${ }^{1}$ Pamela P. Álvarez² ${ }^{\text {, Beatriz Aguirre-Urreta }}{ }^{1}$
}

1 Instituto de Estudios Andinos Don Pablo Groeber (IDEAN), Departamento de Ciencias Geológicas, Facultad de Ciencias Exactas
y Naturales, Universidad de Buenos Aires, Ciudad Universitaria, Pabellón 2, C1428EGA Buenos Aires; Consejo Nacional de In-
vestigaciones Científicas y Técnicas (CONICET).
vvennari@gl.fcen.uba.ar; aguirre@gl.fcen.uba.ar
2 Tehema,Consultores Geológicos EIRL, Virginia Subercaseaux 4100, Pirque, Santiago, Chile.
pamal_ar@yahoo.com

\begin{abstract}
A new ammonoid species of the Andean endemic genus Andiceras Krantz is here described from upper Tithonian-lower Berriasian levels of the Vaca Muerta and Chachao Formations of the Mendoza Group, in north-western Mendoza Province, Argentina. Andiceras planulatus sp. nov. lies between the last beds with representatives of the Substeueroceras koeneni Assemblage Zone of late Tithonian age and the first bed yielding elements of the Argentiniceras noduliferum Assemblage Zone of early Berriasian age, according to the traditional Andean ammonoid zonation scheme. The particular stratigraphic position of Andiceras planulatus, together with its easily recognizable morphology makes this species a good potential biostratigraphic marker for the Jurassic-Cretaceous boundary in the Andean region.
\end{abstract}

Keywords: Ammonoidea, Andiceras, Tithonian, Berriasian, Neuquén Basin, Vaca Muerta Formation, Chachao Formation, Argentina.

RESUMEN. Una nueva especie de Andiceras Krantz (Cephalopoda: Ammonoidea) del Jurásico Tardío-Cretácico Temprano de la Cuenca Neuquina, Mendoza, Argentina. Sistemática y bioestratigrafía. Se describe una nueva especie de amonoideo perteneciente al género andino endémico Andiceras Krantz. Los restos asignados a Andiceras planulatus sp. nov. se disponen estratigráficamente entre los últimos niveles con representantes de la Biozona de Asociación de Substeueroceras koeneni de edad tithoniana tardía, y los primeros elementos de la Biozona de Asociación de Argentiniceras noduliferum de edad berriasiana temprana, de acuerdo al esquema clásico de biozonación andina. La posición estratigráfica particular de esta nueva especie, junto con su morfología de fácil identificación, la convierten en un potencial buen marcador bioestratigráfico para el reconocimiento del límite Jurásico-Cretácico en la región andina.

Palabras clave: Ammonoidea, Andiceras, Tithoniano, Berriasiano, Cuenca Neuquina, Formación Vaca Muerta, Formación Chachao, Argentina. 


\section{Introduction}

The Neuquén Basin of west-central Argentina is located between 32 and $40^{\circ}$ South and comprises a nearly continuous sedimentary infill from Late Triassic to Cenozoic (Fig. 1a). The basin was limited eastward by the Sierra Pintada System, southeastward by the Patagonian Massif, and to the west by a discontinuous volcanic arc which allowed its communication with the Pacific Ocean (Howell et al., 2005). The outcrops extend along a narrow belt over the Central Andes and widen southeastward to form the Neuquén Embayment (Bracaccini, 1970). The Mendoza Group (Groeber, 1946), in the study area, includes the Tordillo (Kimmeridgian), Vaca Muerta (lower Tithonian-lower Berriasian), Chachao (lower Berriasian-lower Valanginian), and the Agrio (upper Valanginian-Hauterivian) Formations. The Vaca Muerta Formation was deposited during one of the most extended transgressions in the basin and it is characterized by the rhythmic alternation of bituminous dark shales, marls and calcareous beds. During the Tithonian the Vaca Muerta Formation was deposited over a homoclinal carbonate-siliciclastic ramp system that probably turned into a distally steepened ramp during the Berriasian (Mitchum and Uliana, 1985; Kietzmann et al., 2008; Kietzmann and Vennari, 2008). The prevailing restricted bottom conditions with deficient oxygenation allowed the excellent preservation of many fossil groups, including a variety of vertebrates and invertebrates, among which ammonoids are the most abundant.

In southern Mendoza, the Vaca Muerta Formation grades up transitionally into the Chachao Formation, characterized principally by yellowish, bioclastic packstones mainly composed by ostreoids and pectinids. From upper Tithonian to lower Berrisian levels of the top of the Vaca Muerta Formation and the base of the Chachao Formation, some ammonoid specimens assignable to a new species have been recovered. Andiceras planulatus sp. nov. is here proposed as a new form of Andiceras Krantz, a genus firstly described from upper Tithonian-lower Berriasian sedimentites in Mendoza Province (Krantz, 1926). This new species may have a high biostratigraphic potential as it is located between the late Tithonian Substeueroceras koeneni and the early Berriasian Argentiniceras noduliferum Assemblage zones. Although two biostratigraphic schemes have been proposed for the Late Jurassic-Early Cretaceous
Andean succession (Leanza, H. 1981a-b; Riccardi, 1988 versus Leanza, H. 1996; Riccardi, 2008), the authors still favour the first one (the traditional one) for reasons later explained in the text.

Most of the material described here was collected by Beatriz Aguirre-Urreta and Pamela Álvarez in the summer of 1995 and it is stored in the Palaeontological Collection of the Buenos Aires University, Argentina (CPBA). For the purpose of comparison, type material of other species included in the genus Andiceras is also figured; these specimens are housed in the Geoscience Centre of the University of Göttingen, Museum, Collections and Geopark, Germany (GZG) (Steuer collection) and in the Steinmann Institute for Geology, Mineralogy and Palaeontology of the Bonn University, Germany (IPB), (Krantz collection).

Dimension of the specimens are indicated in $\mathrm{mm}$ : D: diameter; H: whorl height; W: whorl width and U: umbilical diameter.

\section{Geographical and Geological setting}

The measured Vaca Muerta Formation section $(95 \mathrm{~m})$ is located in western Mendoza, north of Laguna Diamante, on the eastern bank of Arroyo Durazno, near Real de las Coloradas $\left(34^{\circ} \mathrm{S}, 69^{\circ} \mathrm{W}\right)$ (Fig. 1b). It comprises a complete section of the unit, including both its lower contact with the Tordillo Formation and its upper transitional boundary with the Chachao Formation (Fig. 2a).

After a basal microbial laminated mudstone bed, the sedimentary succession continues upward with a monotonous alternation of shales, bearing calcareous nodules, marls with massive and laminar mudstones, and some thin intercalations of calcareous sandstones.

Higher up, the Chachao Formation is represented by bioclastic packstones intercalated with some massive mudstones and marls/shales beds (Fig. 2b).

Ammonites are very abundant all through the section until the base of the Chachao Formation, where shallow-water bivalves start to be dominant. Pectinids, oysters, gastropods and some vertebrate remains are also frequently found associated with the ammonoid fauna. The fossils here described have been collected from levels situated in the last part of the Vaca Muerta Formation and the basal portion of the Chachao Formation, just above a bed yielding representatives of Himalayites andinus Leanza, H. included in the Substeueroceras koeneni 

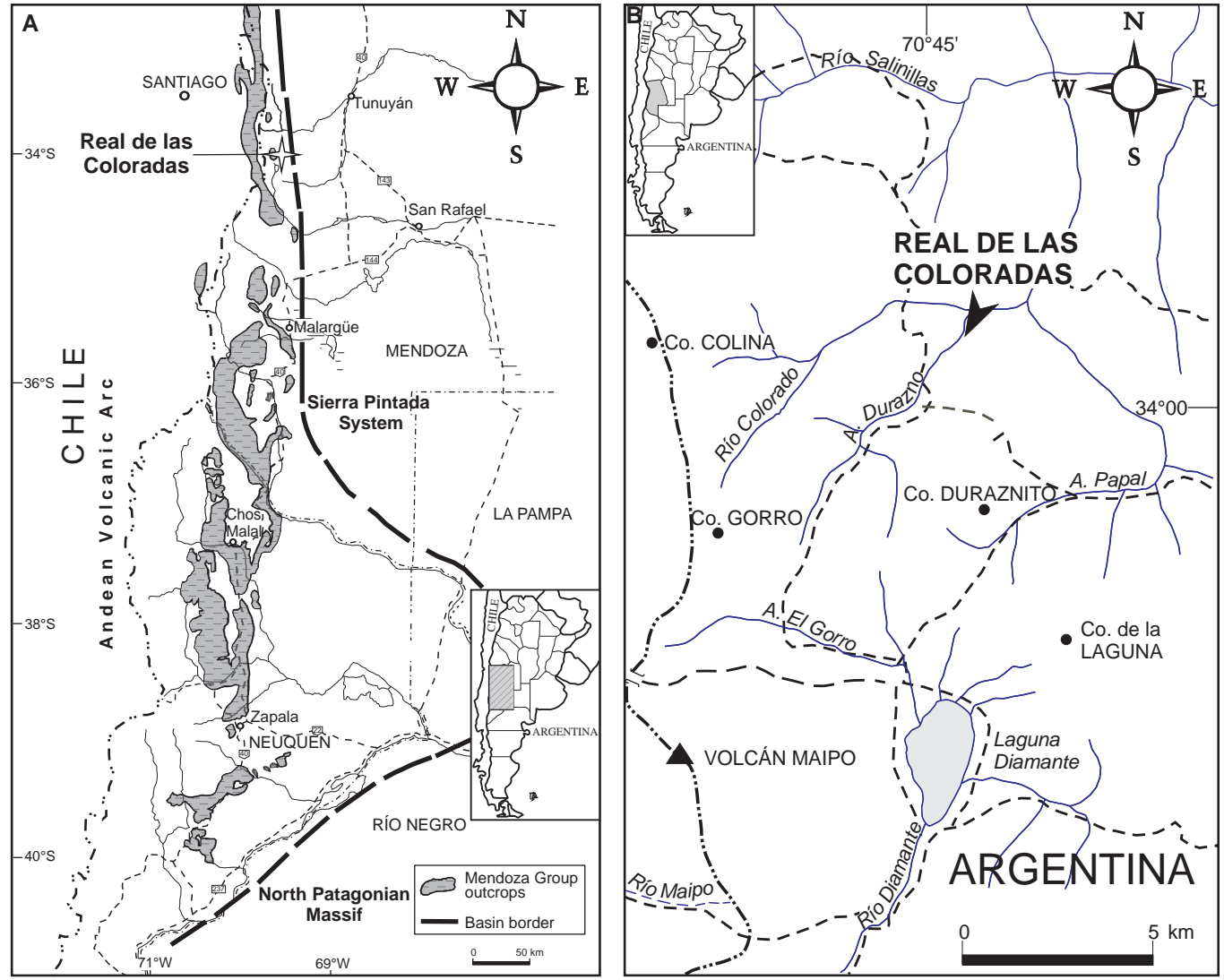

FIG. 1. a. Mendoza Group outcrops in the Neuquén Basin and its boundaries during the Late Jurassic-Early Cretaceous (modified from Gulisano et al., 1984 and Riccardi, 1988); b. Location map of the study area.

Zone, and below levels containing Groebericeras Leanza, A., which has been previously studied by Aguirre-Urreta and Álvarez (1999), and traditionally included in the Argentiniceras noduliferum Zone.

\section{Systematic Paleontology (by Vennari, V.V.)}

\section{Superfamily Perisphinctaceae Steinmann, 1890 \\ Family Neocomitidae Salfeld, 1921 \\ Subfamily Berriasellinae Spath, 1922 Genus Andiceras Krantz, 1926}

\section{? 2011. Krantziceras. Parent et al., p. 40.}

Type species: Andiceras trigonostomum Krantz, 1926 (Krantz, 1928 spanish translation), p. 451, pl. 16, fig. 3, 4. Subsequent designation by Arkell (in Arkell et al., 1957, p. L352). Lectotype designated by Parent et al. (2011) refigured here (Fig. 3 C1-C3).
Remarks: In 1926, Krantz (p. 451, pl. 16, figs. 3, 4) raised the genus Andiceras for some specimens recovered from upper Tithonian-lower Berriasian sediments from the Arroyo Durazno and Arroyo Paraguay localities of the Mendoza Province, Argentina [not from Paraguay as stated in Arkell et al. (1957) and Wright et al. (1996) in both editions of the Treatise on Invertebrate Paleontology: Mollusca 4]. At that time Krantz erected two new species within this genus: A. trigonostomum (type species by subsequent designation by Arkell et al., 1957), and A. acuticostum (Fig. 3A1, A2). Additionally A. cf. theodorii (Burckhardt, non Oppel, 1863), A. theodorii (Steuer, non Oppel) and A. fallax (Steuer) (Fig. 3 B1, B2), were also incorporated into this group by Krantz in the same work. But, although well preserved specimens are known for the last two species, A. cf. theodorii (Burckhardt, 1903, p. 163-164, pl. 10, fig. 21, 22) is figured only as a small 
whorl fragment, on which the generic diagnostic features cannot be well recognized. Unfortunately, we were unable to obtain a modern photograph of the specimen figured as Odontoceras theodorii by Steuer (1897, 1921 Spanish translation) so that it could be included here together with the other type specimens of the species involved in this genus.

The genus Andiceras embraces evolute discoidal shells with subrounded to flattened venters and whorl sections higher than wide, with their maximum width attained at or near the umbilical seam. Whorls sections range from subtriangular with a relatively low $\mathrm{H} / \mathrm{W}$ ratio (A. trigonostomum) to suboval with a higher $\mathrm{H} / \mathrm{W}$ ratio (e.g., A. acuticostum and $A$. planulatus here described). Umbilical seam always rounded but variable pronounced and umbilical wall steeper on outer whorls. Sculpture characterized by dichotomous ribs, sligtly rursiradiate on umbilical wall and rectiradiate to prorsiradiate over the flanks, frequently after rib bifurcation takes place. Some simple and polygyrated ribbing does occur, but intercalary ribs are not observed. On external whorls ribs show no interruption over the venter when shell material is preserved, although a variable persistent ventral depression can be developed. Suture line is characterized by a deep trifid lateral lobe and auxiliary lobes that may exhibit a slight external orientation.
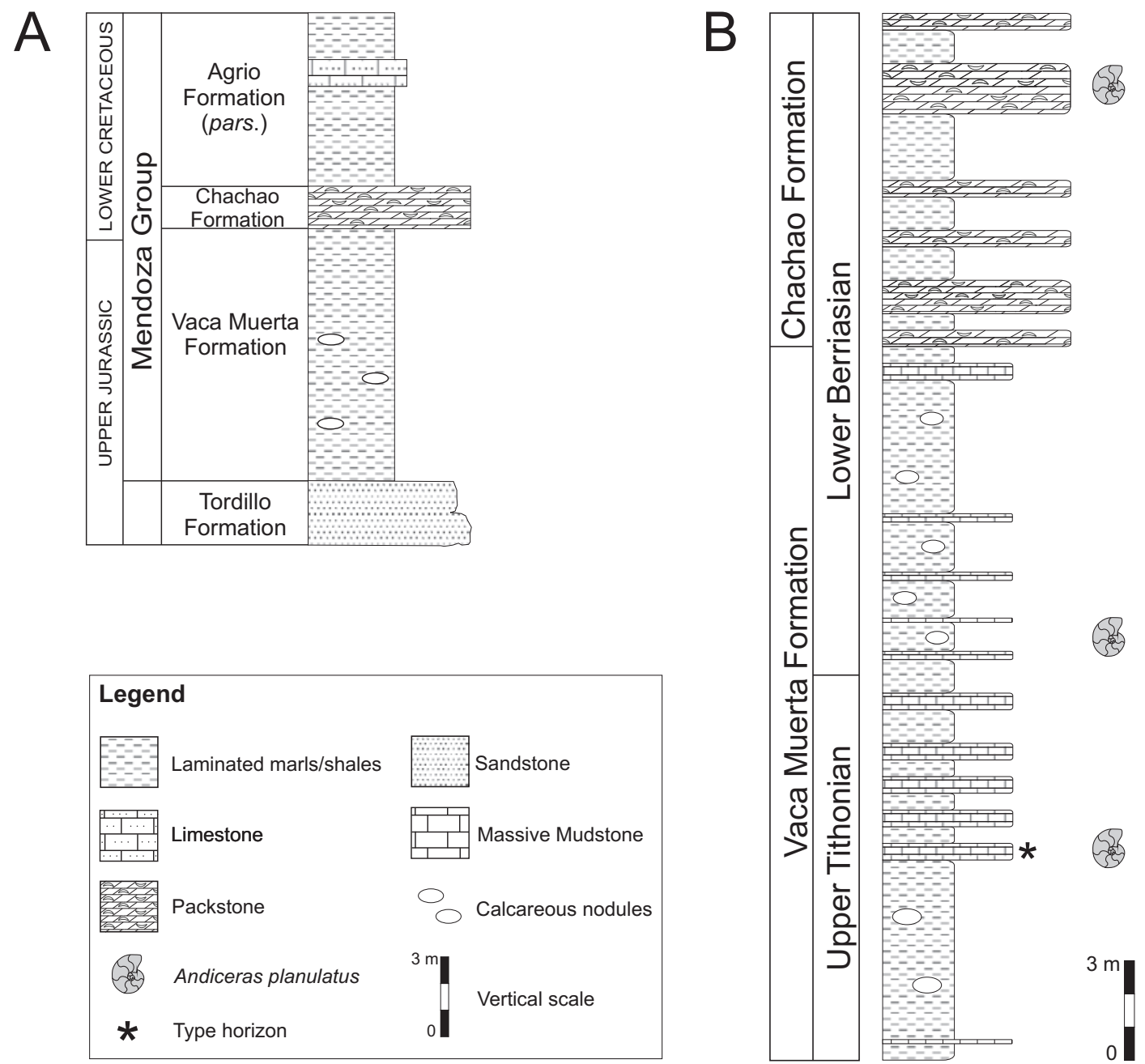

FIG. 2. a. General stratigraphic section of the Mendoza Group in the study area. Not to scale; b. Upper levels of the Real de las Coloradas' stratigraphic section with Andiceras planulatus sp. nov. Vennari beds and type horizon situation. 

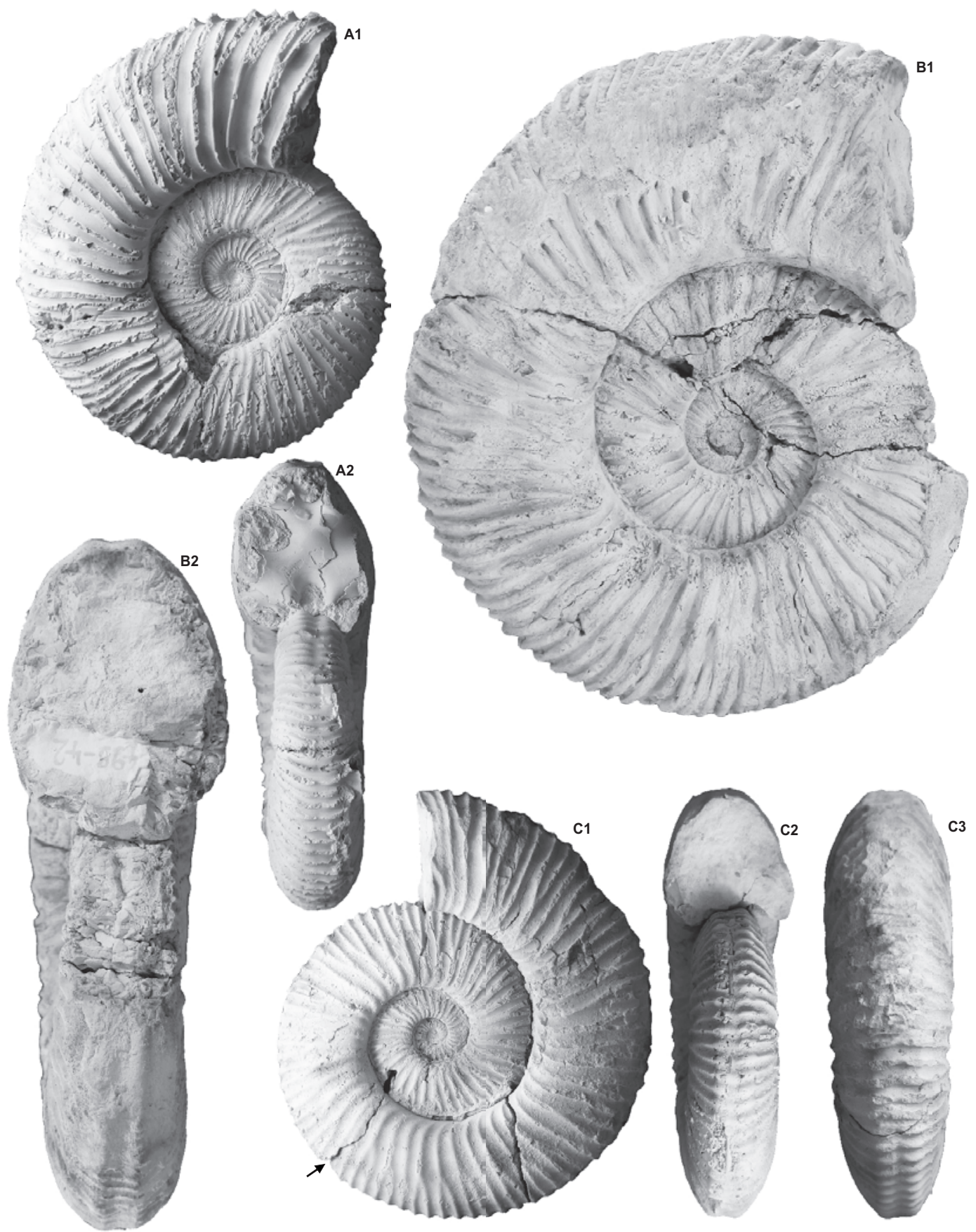

\section{$1 \mathrm{~cm}$}

FIG. 3. A1, A2. Andiceras acuticostum Krantz (1926), Holotype IPB 24. Arroyo Durazno, Mendoza; B1, B2. Andiceras fallax (Steuer non Oppel, 1897), Holotype GZG 499-42 (Steuer Col.). Malargüe, Mendoza; C1, C2, C3. Andiceras trigonostomum Krantz (1926), Andiceras Type species, Holotype IPB 23 (Gerth Col., 1754). Arroyo Paraguay, Mendoza. All specimens recovered from late Tithonian-early Berriasian sediments. The little arrow indicates the beginning of the living chamber. All figures X1. 
Specimens assignable to Andiceras have not been cited frequently in the literature. Five years after Krantz's first description of the genus, Weaver (1931, p. 51) mentioned the presence of Andiceras trigonostomum at a locality in the Vaca Muerta Ridge, near Las Lajas, Neuquén Province. Nevertheless, the association of those specimens with Windhauseniceras internispinosum (Krantz) of middle Tithonian age casts doubts on their identification. More recently, from the Real de las Coloradas section in northern Mendoza, Aguirre-Urreta and Álvarez (1999) mentioned the discovery of some specimens assigned to an 'Andiceras faunule' (some of them figured here), placed between the late Tithonian Substeueroceras koeneni Zone and the early Berriasian Argentiniceras noduliferum Zone. Aguirre-Urreta (2001) then proposed a zone named Andiceras trigonostomum.

The recent concern raised by Parent et al. (2011, p. 42) about the validity of Andiceras is not justified. The genus Andiceras Krantz fits perfectly well the requirements of the Art. No. 12 of the International Code of Zoological Nomenclature (International Commission on Zoological Nomenclature, 1999) so it can not be considered a Nomen Dubium as stated by those authors. Moreover, Krantziceras in Parent et al. (2011, p. 40) is most probably a junior synonym of Andiceras.

Records of Andiceras outside Argentina are dubious and scarce. Spath (1939) included Andiceras fallax in his new genus Parandiceras from northern Pakistan. Some morphological differences, related principally to whorl section and ornamentation, as well as its association with neocomitids of Early Valanginian age (Fatmi, 1977), do not seem to support this designation. From Central America, Verma and Westermann (1973) reported the presence of Andiceras from Mexico. During the revision of the ammonoid fauna from the upper part of El Pastor Member of the La Caja Formation, they assigned Perisphinctes lenki Aguilera, Perisphinctes dolfussi, Aguilera (probably a synonym of the former), and Perisphinctes monserrati Aguilera, (the three of them in Castillo and Aguilera, 1895), to Andiceras. Nevertheless, neither their morphological features nor their stratigraphic position coincide with those of Krantz's genus. Perisphinctes lenki is more involute and exhibits coarser ribbing than the Argentinean forms, and $P$. monserrati's whorl section, markedly wider than high, is dissimilar to that of Andiceras. On the other hand, the associated fauna is composed of
Pseudolissoceras zitteli and Schaireria neoburguensis among other Middle Tithonian genera. They all come from what the authors call Virgatosphinctinae beds, of early mid Tithonian age, as verified by Olóriz et al. $(1996,1999)$ who also figured two new (somewhat distorted) specimens of Andiceras lenki (Aguilera) from the same unit, and one small specimen assigned to Andiceras but without specific designation due to its reduced size and bad preservation (Olóriz et al., 1999). Verma and Westermann (1973) studied specimens are here considered morphologically closer to Aulacosphinctoides, recovered from the same beds, than to Andiceras (e.g., compare the holotype of P. lenki, pl. 43, fig. 2a-b, with Aulacosphinctoides lauri's lectotype, pl. 27, fig. 3a-b in Verma and Westermann's publication).

Also from Mexico, but from the Chinameca Formation, Cantú-Chapa (2006) assigned a small evolute specimen to Andiceras monserrati (Aguilera). Although it superficially resembles Andiceras, its size and the fact that whorl $\mathrm{H} / \mathrm{W}$ ratio is unknown cast doubts on its taxonomic assignment.

In addition to the aforementioned Andiceras references, and the external mould of a whorl fragment of Andiceras (?) sp. of dubious stratigraphic position from Antarctica (Thomson, 1979), the authors do not have knowledge of other specimens assigned to this genus outside western Argentina. Therefore, Andiceras seems to be an endemic genus, of high local biostratigraphic value, due to its particular stratigraphic occurrence and its easily recognizable morphology.

Andiceras planulatus sp. nov. Fig. 4: A-G; Fig. 5: A-H; Fig. 6; Fig. 7E; Table 1

Holotype: Specimen CPBA 20700.1 (Fig. 4 A1-A3). Paratypes: Specimens CPBA 20702.1 (Fig. 4 B1B3) and CPBA 20700.3 (Fig. 4 G1-G3).

Derivation of the name: From its remarkable flat serpenticonic shell.

Additional material: Twenty-two well preserved and almost complete specimens (CPBA 20700.2; CPBA 20700.4-20700.6; CPBA 20701.1-20701.3; CPBA 20702.2-20702.16) from Real de las Coloradas section, Mendoza Province, Argentina.

Type locality and horizon: Western Mendoza, Argentina, Real de las Coloradas section, on the eastern bank of Arroyo Durazno, north of Laguna Diamante. Material comes from a $22 \mathrm{~m}$ interval in the highest beds of the Vaca Muerta Formation and 
TABLE 1. DIMENSIONS OF FIGURED SPECIMENS (mm).

\begin{tabular}{ccccccc}
\hline Specimen & $\mathbf{D}$ & $\mathbf{H}$ & $\mathbf{W}$ & $\mathbf{U}$ & $\mathbf{H} / \mathbf{W}$ & $\mathbf{U} / \mathbf{D}$ \\
\hline CPBA 20700.2 & 49.63 & 16.37 & 12.33 & 22.26 & 1.33 & 0.45 \\
CPBA 20701.1 & 51.62 & 17.28 & 13.56 & 22.64 & 1.27 & 0.44 \\
CPBA 20702.1 & 55.24 & 16.6 & 14.83 & 25.2 & 1.12 & 0.46 \\
CPBA 20702.2 & 63.05 & 19.18 & 15.47 & 30.26 & 1.24 & 0.48 \\
CPBA 20702.3 & $77.83^{*}$ & 20.01 & $15.72^{*}$ & 39.16 & - & - \\
CPBA 20701.2 & $74^{*}$ & $20.98^{*}$ & $12.75^{*}$ & 36.87 & - & - \\
CPBA 20700.3 & 76.87 & 20.97 & $12.20^{*}$ & 40.83 & - & 0.53 \\
CPBA 20701.3 & 84.35 & 24.4 & 16.48 & 40.15 & 1.48 & 0.48 \\
CPBA 20700.1 & 101.38 & 27.83 & 22.43 & 52.05 & 1.24 & 0.51 \\
CPBA 20702.6 & 58.53 & 20.35 & 16.26 & 25.71 & 1.25 & 0.44 \\
CPBA 20702.7 & 66.97 & 21.5 & 16.21 & 31.52 & 1.33 & 0.47 \\
CPBA 20702.9 & 38.64 & 12.22 & 9.77 & 16.17 & 1.25 & 0.42 \\
CPBA 20702.10 & 34.36 & 12.9 & 9.72 & 13.72 & 1.33 & 0.40 \\
CPBA 20702.11 & $115.3 *$ & 32.89 & - & 54.75 & - & - \\
CPBA 20700.5 & $55.12 *$ & 17.9 & 14.01 & 31.64 & 1.28 & - \\
\hline
\end{tabular}

D: Diameter; H: whorl height; W: whorl width; U: umbilical diameter.

* Approximate measurement

the basal portion of the Chachao Formation (Fig. 2B). Type horizon containing the holotype CPBA 20700.1 and the paratype CPBA 20700.3 is situated $70 \mathrm{~m}$ above the base of the section and $14.5 \mathrm{~m}$ below the first bioclastic packstone intercalation of the Chachao Formation. It consists of a $0.5 \mathrm{~m}$ thick laminated mudstone bed. The paratype CPBA 20702.1 is located $12 \mathrm{~m}$ upwards in a $1.5 \mathrm{~m}$ thick bioclastic packstone.

Diagnosis: Andiceras characterized by its strong evolution and flattened outline.

Description: Serpenticone discoidal shell, strongly evolute (mean $\mathrm{U} / \mathrm{D}=0.47 \mathrm{~mm}$ ). Largest specimen may reach more than $115 \mathrm{~mm}$ in diameter. Body chamber only partially preserved (1/4 whorl length or less) in four specimens (Fig. 4C and 5A2, B2, and D1). Almost parallel flat flanks becoming slightly more rounded with age (Fig. 7E). Venter gently convex. Whorl section compressed, higher than wide (mean $\mathrm{H} / \mathrm{W}=1.28 \mathrm{~mm}$ ), maximum whorl breadth attained around the umbilical border. Very shallow rounded umbilical wall, although slightly more pronounced on outer whorls. Ornamentation characterized by low- relief fine ribs, gently rursiradiate on umbilical wall, bent forward at the umbilical angle and rectiradiate to slightly prorsiradiate over the flanks. Most of primary ribs bifurcate near the middle of the flanks, some remain simple though in a few cases polygyrate branching does occur. No true constrictions are observed but some intercostal spaces may be reduced when a simple rib takes place. Ribs interrupted by a narrow and shallow ventral furrow up to a $20 \mathrm{~mm}$ diameter, on both sides of which, each rib swells slightly. After that, and when the complete thickness of the recrystallized shell material is preserved, ribs suffer a marked ventral depression but show no interruption until the shell reaches a diameter of $80 \mathrm{~mm}$. Whenever the internal mould is preserved, a narrow ventral furrow accompanied by slightly swollen ribs at its sides is still visible. On outer whorls ribbing is continuous and passes straight over the venter with no depression. Portions of living chamber preserved show no change in ornamentation. Apertural modifications are unknown. Suture line well indented, characterized by narrow saddles and a deep trifid lateral lobe (Fig. 6). 


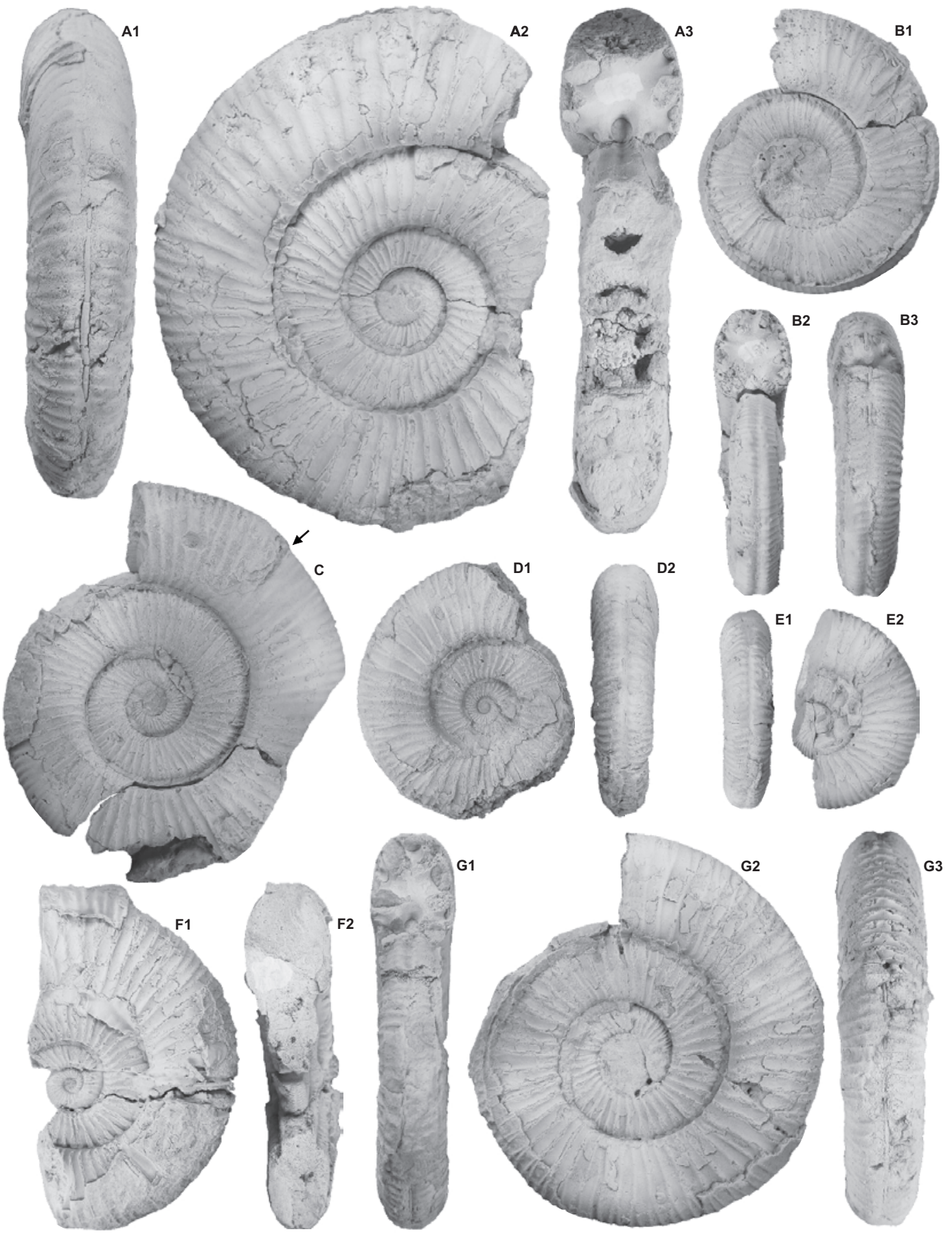

$1 \mathrm{~cm}$

FIG. 4. Andiceras planulatus Vennari sp. nov. late Tithonian-early Berriasian of Real de las Coloradas section. A1, A2, A3, CPBA 20700.1 Holotype; B1, B2, B3, CPBA 20702.1 Paratype; C, CPBA 20702.3; D1, D2, CPBA 20700.2; E1, E2, CPBA 20702.9; F1, F2, CPBA 20702.7; G1, G2, G3, CPBA 20700.3 Paratype. The little arrow indicates the beginning of the living chamber. All figures X1. 


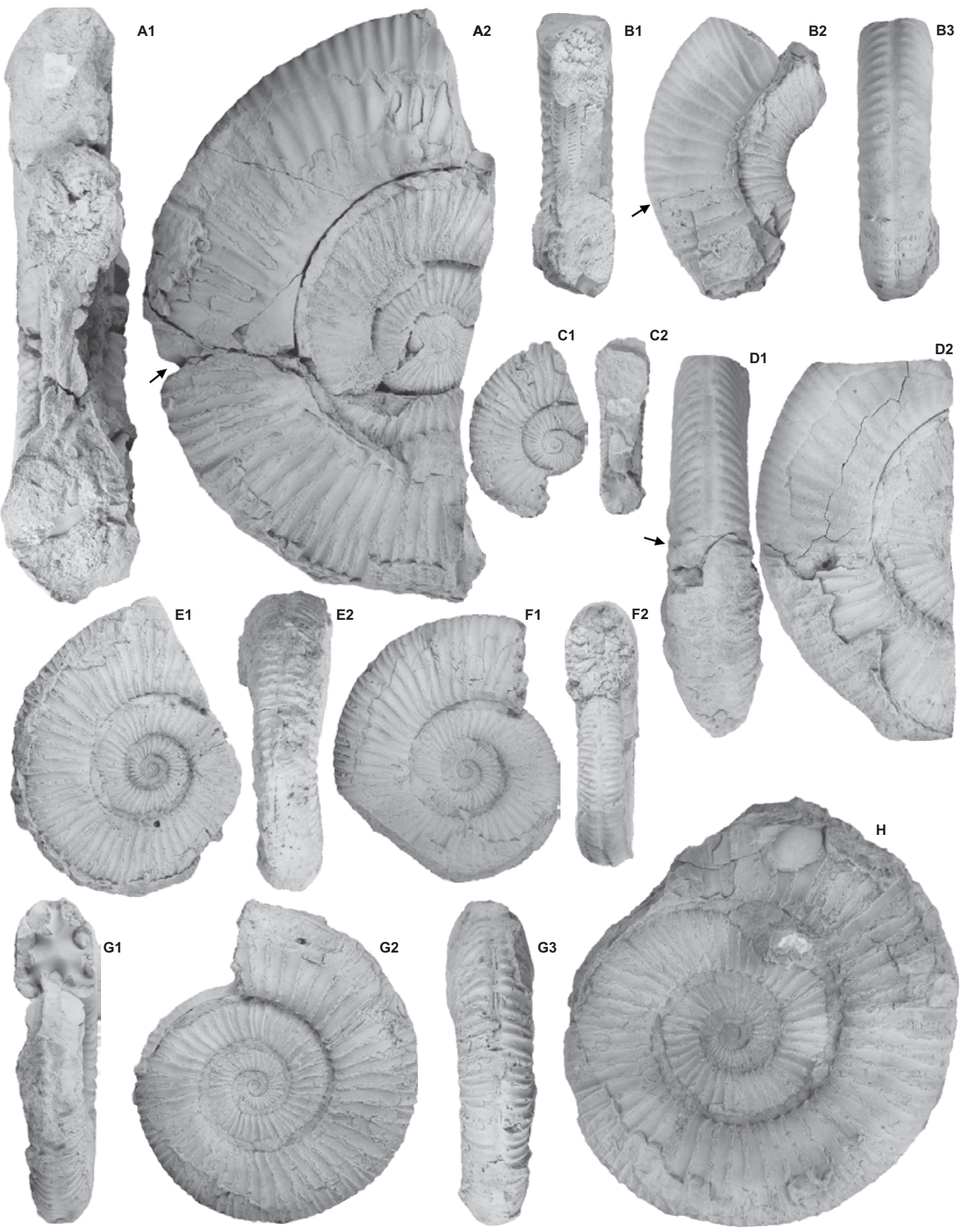

$1 \mathrm{~cm}$

FIG. 5. Andiceras planulatus Vennari sp. nov. late Tithonian-early Berriasian of Real de las Coloradas section. A1, A2, CPBA 20702.11; B1, B2, B3, CPBA 20700.5; C1, C2, CPBA 20702.10; D1, D2, CPBA 20701.2; E1, E2, CPBA 20702.6; F1, F2, CPBA 20701.1; G1, G2, G3 CPBA 20702.2; H, CPBA 20701.3. The little arrow indicates the beginning of the living chamber. All figures X1. 


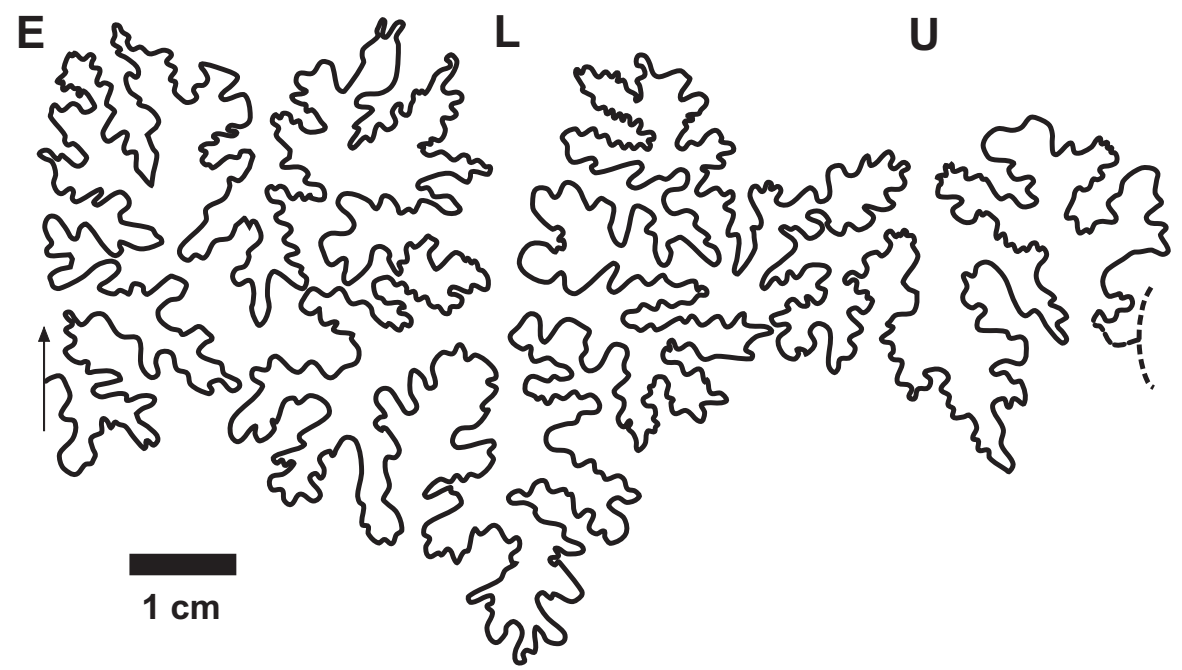

FIG. 6. Andiceras planulatus sp. nov. suture line. E: external lobe, L: lateral lobe, U: umbilical lobe. CPBA 20702.1 X10

Remarks: Inclusion of Andiceras planulatus in this genus is well supported by its general morphology, ribbing pattern and suture line. Nevertheless, its strong degree of evolution and markedly flat whorl section throughout ontogeny makes this species quite easily differentiable from others. From the group of species originally included by Krantz (1926) in his new genus Andiceras, (A. trigonostomum and $A$. acuticostum Krantz, A. theodorii Steuer non Oppel, A. cf. theodorii Burckhardt non Oppel and A. fallax Steuer), A. acuticostum and A. theodorii have the closest morphology to Andiceras planulatus (see schematic tranversal sections on Fig. 7A-7E), but both exhibit lesser degrees of evolution and more rounded outlines, and A. Theodorii, particularly, shows a notable persistence of the ventral groove on the outer whorls. A. trigonostomum differs from A. planulatus by its triangular whorl outline and the persistency of the ventral depression over the living chamber. Finally, A. fallax presents very rounded flanks, a markedly steep umbilical wall and a ventral depression that accompanies the entire phragmocone (diameter $=130 \mathrm{~mm}$ ), all characters clearly different from those typical of A. planulatus.

\section{Stratigraphic distribution and discussion of age}

Up to the present, Andiceras planulatus has only been proved to be represented in the western Neuquén Basin in a thin interval included in the upper portion of the Vaca Muerta Formation and the basal
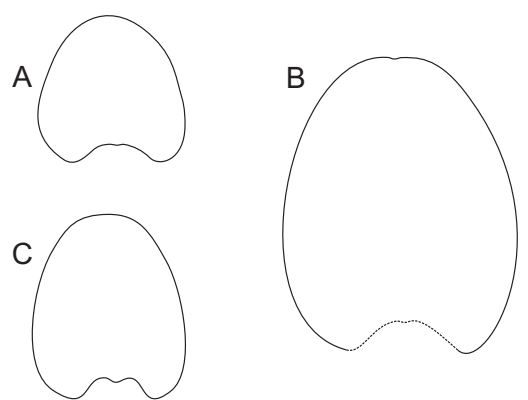

$1 \mathrm{~cm}$
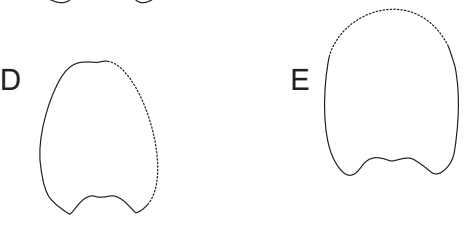

FIG. 7. Andiceras group whorl sections. A. Andiceras trigonostomum Krantz, Andiceras Type species, Holotype IPB 23 (Gerth Col. 1754); B. Andiceras fallax (Steuer), Holotype GZG 499-42 (Steuer Col.); C. Andiceras acuticostum Krantz, Holotype IPB 24; D. Andiceras theodorii (Steuer non Oppel) refigured from Steuer 1921; E. Andiceras planulatus Vennari sp. nov, CPBA 20700.1. All figures X1.

part of Chachao Formation. The first specimens have been found immediately above the last levels with Parodontoceras calistoides (Behrendsen), and below one containing Himalayites andinus, all placed in the Substeueroceras koeneni Zone (Table 2). A. planulatus increases in abundance upwards 
TABLE 2. AMMONOID BIOSTRATIGRAPHY OF THE NEUQUÉN BASIN AND ITS CORRELATION WITH THE TETHYS/MEDITERRANEAN REGION.*

\begin{tabular}{|c|c|c|c|c|}
\hline \multirow{2}{*}{\multicolumn{2}{|c|}{ Stage }} & \multicolumn{2}{|c|}{ Tethys/Mediterranean } & \multirow{2}{*}{$\begin{array}{c}\text { Neuquén Basin } \\
\text { Zone }\end{array}$} \\
\hline & & Zone & Subzone & \\
\hline \multirow{4}{*}{$\frac{z}{4}$} & \multirow{4}{*}{ Upper } & \multirow{4}{*}{ Subthurmannia boissieri } & Thurmanniceras otopeta & \multirow{4}{*}{ Spiticeras damesi } \\
\hline & & & Tirnovella alpillensis & \\
\hline & & & Berriasella picteti & \\
\hline & & & Malbosiceras paramimounum & \\
\hline \multirow{4}{*}{$\begin{array}{l}\bar{\alpha} \\
\frac{\sim}{w} \\
\bar{\infty}\end{array}$} & \multirow{3}{*}{ Middle } & \multirow{3}{*}{ Subthurmannia occitanica } & Dalmasiceras dalmasi & \multirow{3}{*}{ Argentiniceras noduliferum } \\
\hline & & & Berriasella privasensis & \\
\hline & & & Subthurmannia subalpina & \\
\hline & Lower & Berriasella jacobi & & \multirow{2}{*}{ Andiceras planulatus } \\
\hline \multirow{4}{*}{ 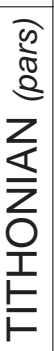 } & \multirow{4}{*}{ Upper } & \multirow[b]{2}{*}{ Durangites } & & \\
\hline & & & & Substeueroceras koeneni \\
\hline & & \multirow{2}{*}{$\begin{array}{l}\text { Micracanthoceras } \\
\text { microcanthum }\end{array}$} & $\begin{array}{l}\text { Paraulacosphinctes } \\
\text { transitorius }\end{array}$ & Corongoceras alternans \\
\hline & & & Simplisphinctes & $\begin{array}{l}\text { Windhauseniceras } \\
\text { internispinosum }\end{array}$ \\
\hline
\end{tabular}

* Neuquén Basin late Tithonian biozonation after Zeiss and Leanza, H. (2008), Berriasian after Aguirre-Urreta et al. (2007). Tethys/ Mediterranean late Tithonian biozonation after Ogg et al. (2008) and Berriasian after Reboulet et al. (2011). Andiceras planulatus biostratigraphic situation in grey.

until the first occurrence of Groebericeras bifrons within the Argentiniceras noduliferum Zone. Some of the associated ammonoid fauna includes Himalayites egregius (Steuer), Micracanthoceras lamberti Leanza, A., Substeueroceras subfasciatum (Steuer) and Berriasella sp.

The position of the $S$. koeneni Zone around the Jurassic-Cretaceous boundary has undergone some changes in recent years. It was traditionally placed in the latest Tithonian-equivalent to the Tethyan Durangites Zone-(Leanza, A. 1945; Leanza, H. 1981a, b; Riccardi, 1988), but according to a new Andean ammonite zonation presented by Leanza, $\mathrm{H}$. (1996), the S. koeneni Zone would not only embrace the $\mathrm{J} / \mathrm{K}$ boundary, but it also would extend into the early mid Berriasian-including the late Tethyan Durangites, Berriasella jacobi and early Tirnovella occitanica Zones-(Riccardi et al., 2000; Riccardi, 2008). Although the reasons for these displacements are outside the scope of this paper, we should point out that Schaireria longaeva (Leanza, A.) is still considered a late Tithonian species as originally designated by its author (see correlation chart in
Leanza, A. 1945) and not of early Berriasian age, as misinterpreted by Checa (1985) in correlating with Betic specimens -a situation already pointed out by Cantú-Chapa (2006). On the other hand, the proposal of 'Spiticeras' acutum Gerth as a forerunner of Groebericeras of berriasian age (Leanza, H. 1996) is still not well supported, and currently its recombination as Proniceras acutum is under evaluation (Vennari, in preparation).

So far neither microfossils assemblages nor magnetostratigraphic data are available to improve the resolution of the Tithonian-Berriasian boundary beds in the Andean Region, and similarly to the situation of the Berrias Stratotype Section (Hoedemaeker and Reboulet, 2003) no lithological variations in the Upper Jurassic-Lower Cretaceous sedimentary column have been yet recognized (Harrington, 1962).

Thus, until new findings allow an accurate ammonite zonation for this interval, we still favour the traditional Andean scheme (Leanza, H. 1981a, b; Riccardi, 1988) in which a latest Tithonian-earliest Berriasian age is indicated for Andiceras planulatus bearing in mind its stratigraphic situation between 
levels with representatives of the Family Himalayitidae, outstanding component of the Tethyan Durangites zone according to Tavera et al. (1986), and Groebericeras bifrons, which up to the present has never been recorded in the late Berriasian Spiticeras damesi Zone probably equivalent to the Tethyan Berriasella boissieri Zone of south-east France (Leanza, H. 1981a, b).

\section{Conclusions}

Andiceras planulatus, a new species of the Andean genus Andiceras Krantz is here presented and described. A. planulatus comes from upper Tithonian-lower Berriasian levels in Real de las Coloradas section. The stratigraphic position of this new species along with its particular morphological characters make it a potentially important biostratigraphic marker for the Jurassic-Cretaceous boundary in the Andean region.

\section{Acknowledgements}

The authors are most grateful to Dr. M. Reich, curator of the geoscientific collections and associated director of the Geowissenshaftliches Museum of the Georg August University of Göttingen and to Dr. S. Kaiser, curator of the Institute for Palaeontology, University of Bonn for access to the fossils under their care. Special thanks are given to the reviewers Dr. F. Olóriz (Universidad de Granada, Spain), Dr. A. Rubilar (Servicio Nacional de Geología y Minería, SERNAGEOMIN, Chile) and Dr. W. Wimbledon (Bristol University, England) for their valuable comments. We are also thankful to Dr. Wimbledon for improving the English of the manuscript. This paper is the contribution number R-02 of the Instituto de Estudios Andinos 'Don Pablo Groeber' (IDEAN) and was financied by the PICT2006-00189, 'Estudio paleontológico integral de la Cuenca Neuquina en el intervalo Tithoniano-Aptiano’.

\section{References}

Aguirre-Urreta, M.B. 2001. Marine Upper Jurassic-Lower Cretaceous stratigraphy and biostratigraphy of the Aconcagua-Neuquén Basin, Argentina and Chile. Journal of Iberian Geology 27: 71-90.

Aguirre-Urreta, M.B.; Álvarez, P.P. 1999. The Berriasian genus Groebericeras in Argentina and the problem of its age. Scripta Geologica Special Issue 3: 15-29.

Aguirre-Urreta, M.B.; Mourgues, F.A.; Rawson, P.F.; Bulot, L.G.; Jaillard, E. 2007. The Lower Cretaceous
Chañarcillo and Neuquén Andean basins: ammonoid biostratigraphy and correlations. Geological Journal 42: 143-173.

Arkell, W.J.; Kummel, B.; Wright, C.W. 1957. Mesozoic ammonoidea. In Treatise on Invertebrate Paleontology, Part L, Mollusca 4, Cephalopoda, Ammonoidea (Moore, R.C.; editor). Geological Society of America and Kansas Press: L80-L441. Kansas.

Bracaccini, O. 1970. Rasgos tectónicos de las acumulaciones mesozoicas en las provincias de Mendoza y Neuquén, República Argentina. Revista de la Asociación Geológica Argentina 25 (2): 275-284.

Burckhardt, C. 1903. Beitrage zur Kenntniss der Jura und Kreide formation der Cordillere. Palaeontographica 50 (1-3): 1-144.

Cantú-Chapa, A. 2006. New Upper Tithonian (Jurassic) Ammonites of the Chinameca Formation in Southern Veracruz, Eastern Mexico. Journal of Paleontology 80 (2): 294-308.

Castillo, A.D.; Aguilera, J.G. 1895. Fauna fósil de la Sierra de Catorce, San Luis Potosí. Boletín de la Comisión Geológica Mexicana 1: 55 p.

Checa, A. 1985. Los aspidoceratiformes en Europa (Ammonitina, Fam. Aspidoceratidae: Subfamilias Aspidoceratinae y Physodoceratinae). Ph.D. Thesis (Unpublished), Universidad de Granada: 413 p.

Fatmi, A.N. 1977. Neocomian ammonites from northern areas of Pakistan. Bulletin of the British Museum of Natural History, Geology 28: 257-296.

Groeber, P. 1946. Observaciones geológicas a lo largo del meridiano 70.1. Hoja Chos Malal. Revista de la Asociación Geológica Argentina 1: 177-208.

Gulisano, C.A.; Gutiérrez Pleimling, A.; Digregorio, R.E. 1984. Análisis estratigráfico del intervalo TithonianoValanginiano (Formaciones Vaca Muerta, Quintuco y Mulichinco) en el suroeste de la provincia del Neuquén. In Congreso Geológico Argentino No. 9, Actas 1: 221-235. Bariloche.

Harrington, H.J. 1962. Paleogeographic development of South America. American Association of Petroleum Geologists, Bulletin 46: 1773-1814.

Hoedemaeker, P.J.; Reboulet, S. (Reporters); AguirreUrreta, M.B.; Alsen, P.; Aoutem, M.; Atrops, F.; Barragan, R.; Company, M.; González-Arréola, C.; Klein, J.; Lukeneder, A.; Ploch, I.; Raisossadat, N.; Rawson, P.F.; Ropolo, P.; Vašícek, Z.; Vermeulen, J.; Wippich, M.G.E. 2003. Report on the First International Workshop of the International Union of Geological Sciences (IUGS) Lower Cretaceous Ammonite Working Group, the ‘Kilian Group’ (Lyon, 
11 July 2002). Cretaceous Research 24 (1): 89-94 and 24 (6): p. 805 (Erratum).

Howell, J.A.; Schwarz, E.; Spalleti, L.A.; Veiga, G.D. 2005. The Neuquén Basin: an overview. In The Neuquén Basin, Argentina: A case study in Sequence Stratigraphy and basin dynamics (Veiga, G.D.; Spalleti, L.A.; Howell, J.A.; Schwarz, E.; editors). The Geological Society of London Special Publications 252: 1-14. London.

International Commission on Zoological Nomenclature (ICZN). 1999. International Code for Zoological Nomenclature, 4th Ed. International Trust for Zoological Nomenclature: 306 p. London.

Kietzmann, D.A.; Vennari, V.V. 2008. Facies, ambiente depositacional y estratigrafía de la Formación Vaca Muerta (Tithoniano inferior-Berriasiano superior) en el área del Cerro Domuyo, Neuquén. In Congreso Geológico Argentino No. 17, Actas 2: 773. Jujuy.

Kietzmann, D.A.; Palma, R.M.; Bressan, G.S. 2008. Facies y microfacies de la rampa tithoniana-berriasiana de la Cuenca Neuquina (Formación Vaca Muerta) en la sección del Arroyo Loncoche-Malargüe, provincia de Mendoza. Revista de la Asociación Geológica Argentina 63 (4): 696-713.

Krantz, F. 1926. Die ammoniten des Mittel- und Obertithons. In Beiträge zur Paläontologie und Stratigraphie des Lias, Doggers, Tithons und der Unterkreide in der Kordillere im Süden der Provinz Mendoza (Argentinien) (Jaworski, E.; Krantz, F.; Gerth, E.; editors). Geologische Rundschau 17a: 427-462.

Krantz, F. 1928. La fauna del Titono superior y medio en la parte meridional de la provincia de Mendoza. Academia Nacional de Ciencias, Actas 10: 1-57. Córdoba.

Leanza, A.F. 1945. Ammonites del Jurásico Superior y del Cretácico Inferior de la Sierra Azul, en la parte meridional de la provincia de Mendoza. Anales del Museo de La Plata, Nueva Serie 1: 99 p.

Leanza, H.A. 1981a. Faunas de ammonites del Jurásico y Cretácico inferior de América del Sur, con especial consideración de la Argentina. In Cuencas Sedimentarias de América del Sur (Volkheimer, W.; Musacchio, E.; editors) 2: 559-597. Buenos Aires.

Leanza, H.A. 1981b. The Jurassic-Cretaceous boundary beds in West Central Argentina and their ammonite zones. Neues Jahrbuch für Mineralogie, Geologie und Paläontologie, Abhandlungen 161 (1): 62-92.

Leanza, H.A. 1996. Advances in the ammonite zonation around the Jurassic/Cretaceous boundary in the Andean Realm and correlation with Tethys. In Jost Wiedmann Symposium, Abstracts: 215-219. Tübingen.
Mitchum, R.M.; Uliana, M.A. 1985. Seismic stratigraphy of carbonate depositional sequences, Upper JurassicLower Cretaceous, Neuquén Basin, Argentina. In Seismic Stratigraphy, II: an Integrated Approach to Hydrocarbon Exploration (Berg, O.; Woolverton, D.; editors). American Association of Petroleum Geologist Memoirs 39: 255-274.

Ogg, J.G.; Ogg, G.; Gradstein, F.M. 2008. The concise geologic time scale. Cambridge University Press: 177 p. Cambridge.

Olóriz, F.; Villaseñor, A.B.; González-Arreola, C.; Westermann, G.E.G. 1996. Interpreting updated ammonite biostratigraphy. The Upper Jurassic-Lowermost Cretaceous in the Alamitos area, Sierra de Catorce, San Luis Potosí (North Central Mexico). In International Symposium on Cephalopods-Present and Past, No. 4, Abstract (Olóriz, F.; Rodríguez-Tovar, F.J.; editors): 134-136. Granada.

Olóriz, F.; Villaseñor, A.B.; González-Arreola, C.; Westermann, G.E.G. 1999. Ammonite biostratigraphy and correlations in the Upper Jurassic-Lowermost Cretaceous La Caja Formation of North-Central México (Sierra de Catorce, San Luis Potosí). In Advancing Research on Living and Fossil Cephalopods (Olóriz, F.; Rodríguez-Tovar, F.J.; editors). Kluwer Academic/ Plenum Publishers: 463-492. New York.

Oppel, A. 1863. Über ostindische Fossilreste aus den secündaren Ablagerungen von Spiti und Gnari-Khorsum in Tibet. Palaeontologische Mittheilungen aus dem Museum des Koenigliche Bayerisches Staates 1: 267-322.

Parent, H; Scherzinger, A.; Schweigert, G. 2011. The Tithonian-Berriasian ammonite fauna and stratigraphy of Arroyo Cieneguita, Neuquén-Mendoza Basin, Argentina. Boletín del Instituto de Fisiografía y Geología 79-81: 21-94.

Reboulet, S.; Rawson, P.F.; Moreno-Bedmar, J.A.; AguirreUrreta, M.B.; Barragan, R.; Bogomolov, Y.; Company, M.; González-Arreola, C.; Stoyanova, V.I.; Lukeneder, A.; Matrion, B.; Mitta, V.; Randrianaly, H.; Vašicek, Z.; Baraboshkin, E.J.; Bert, D.; Bersac, S.; Bogdanova, T.N.; Bulot, L.G.; Latil, J.-L.; Mikhailova, I.A.; Ropolo, P.; Szives, O. 2011. Report on the 4th International Meeting of the International Union of Geological Sciences (IUGS) Lower Cretaceous Ammonite Working Group, the 'Kilian Group’ (Dijon, France, 30th August 2010. Cretaceous Research 32: 786-793.

Riccardi, A.C. 1988. The Cretaceous System of southern South America. Geological Society of America, Memoir 168: 1-161. 
Riccardi, A.C. 2008. El Jurásico de la Argentina y sus amonites. Revista de la Asociación Geológica Argentina 63 (4): 625-643.

Riccardi, A.C.; Leanza H.A.; Damborenea, S.E.; Manceñido, M.O.; Ballent, S.C.; Zeiss, A. 2000. Marine Mesozoic Biostratigraphy of the Neuquén Basin. Zeitschrift für Angewandte Geologie, Sonderheft 1: 103-108.

Salfeld, H. 1921. Kiel- und Furschenbildung auf der Schalenaussenseite der Ammonoideen in ihrer Bedeutung für die Systematik und Festlegung von Biozonen. Zentralblatt für mineralogie, Geologie und Paläontologie 1921: 343-347.

Spath, L.F. 1922. On Cretaceous Ammonoidea from Angola, collected by Professor J.W. Gregory, D. Sc., F.R.S. Transactions of the Royal Society of Edinburgh 53: 91-160.

Spath, L.F. 1939. The Cephalopoda of the Neocomian Belemnite Beds of the Salt Range, Memoirs of the Geological Survey of India, Palaeontología Indica (New Series) 25 (1): 154 p.

Steinmann, G. 1890. Cephalopoda. In Elemente der Paläontologie (Steinmann, G. ; Döderlein, L.; editors). Engelmann, W.: 344-475. Leipzig.

Steuer, A. 1897. Argentinischen Jura Ablagerungen. Beitrag zur Kenntniss der Geologie und Paläontologie der argentinischen Anden. Palaeontologische Abhandlungen 7, neue folge 3: $222 \mathrm{p}$.

Steuer, A. 1921. Estratos Jurásicos Argentinos. Contribución al conocimiento de la geología y paleontología de los Andes Argentinos entre el río Grande y el río Atuel. Actas de la Academia Nacional de Ciencias 7: 33-125. Córdoba.

Tavera, J.M.; Checa, A.; Olóriz, F.; Company, M. 1986. Mediterranean ammonites and the Jurassic-Cretaceous boundary in southern Spain (Subbetic Zone). Acta. Geologica Hungarica 29 (1-2): 151-159.

Thomson, M.R.A. 1979. Upper Jurassic and Lower Cretaceous ammonite faunas of the Ablation Point Area, Alexander Island. British Antartic Survey Scientific Reports No. 97: 37 p.

Verma, H.M.; Westermann, G.E.G. 1973. The Tithonian (Jurassic) ammonite fauna and Stratigraphy of Sierra Catorce, San Luis Potosí, México. Bulletins of American Paleontology 63 (277): 108-137.

Weaver, C. 1931. Paleontology of the Jurassic and Cretaceous of west-central Argentina. University of Washington Memoirs 1: 1-595.

Wright, C.W.; Callomon, J.H.; Howarth, M.K. 1996. Treatise on Invertebrate Paleontology Part L, Mollusca 4 (Revised). Volume 4 Cretaceous Ammonoidea. Geological Society of America and the University of Kansas Press: 362 p. Kansas.

Zeiss, A.; Leanza, H.A. 2008. Interesting new ammonites from the Upper Jurassic of Argentina and their correlation potential: New possibilities for global correlations at the base of the Upper Tithonian by ammonites, calpionellids and other fossil groups. Newsletters on Stratigraphy 42 (3): 223-247.

Manuscript received: October 29, 2010; revised/accepted: June, 21, 2011; available online: July 18, 2011. 